\title{
Occurrence of insomnia and daytime somnolence among professional drivers
}

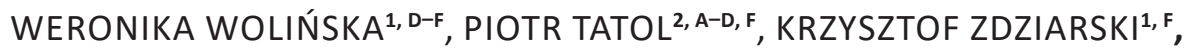 \\ IWONA EWA KARPETA-PAWLAK ${ }^{1, D}$, BOŻENA MROCZEK ${ }^{1, A, D, E}$ \\ ${ }^{1}$ Department of Humanities in Medicine, Pomeranian Medical University, Szczecin, Poland \\ ${ }^{2}$ Voivodship Emergency Services Station in Szczecin, Poland
}

A - Study Design, B - Data Collection, C - Statistical Analysis, D - Data Interpretation, E - Manuscript Preparation, F - Literature Search, G - Funds Collection

Summary Background. Insomnia is described as an insufficient amount or quality of sleep that lasts for at least a month. Sleeplessness in the group of professional drivers may lead to accidents and other road incidences. Factors influencing the work of drivers include their work time - the amount of time they spend driving their vehicle.

Objectives. The aim of the study was to estimate the frequency of the occurrence of insomnia among professional drivers, taking into consideration daytime sleepiness, socio-demographic variables and hourly work organization.

Material and methods. Study was conducted on 94 professional drivers from the Zachodniopomorskie region: 25 (26.60\%) paramedics, 24 (25.53\%) police officers, $23(24.47 \%)$ fire fighter drivers and 23 (24.47\%) truck drivers. A questionnaire was used with the following components: Athens Insomnia Scale (AIS), Epworth Sleepiness Scale (ESS) and an original questionnaire containing questions regarding socio-demographic data and health behaviors.

Results. Insomnia was diagnosed in 12 professional drivers (12.77\%). Among them the majority were truck drivers -4 respondents $(4.26 \%)$. A relationship between the age of respondents and occurrence of insomnia measured with the AIS scale was found. A relationship between insomnia and drivers posing a threat to road traffic was also found $\left(\chi^{2}=19.95 ; p=0.005\right)$. People suffering from moderate daytime sleepiness are 35 years old on average.

Conclusions. Drivers older than 35 and those with BMI above 28 are groups with the highest risk of suffering from insomnia. Drivers with insomnia more frequently pose a threat to road traffic. Drinking coffee has no impact on insomnia and daytime sleepiness. Key words: insomnia, drivers, Epworth Sleepiness Scale, Athens Insomnia Scale.

Wolińska W, Tatol P, Zdziarski K, Karpeta-Pawlak IE, Mroczek B. Occurrence of insomnia and daytime somnolence among professional drivers. Fam Med Prim Care Rev 2017; 19(3): 277-282, doi: https://doi.org/10.5114/fmpcr.2017.69291.

\section{Background}

Insomnia is described as an insufficient amount or quality of sleep that lasts for at least a month. In order to assess the actual occurrence of insomnia, patients ought to record their problems with sleeping at least 3 times a week for at least a month. The main criterion indicating the occurrence of insomnia according to ICD-10 is highly limited functionality during the day and bad mood [1]. Insomnia is a disorder occurring in people of various ages $[2,3]$. It is the resultant of factors that are predisposing, triggering and preserving [4]. All mentioned factor groups of various origins were combined in a way that presents their mutual interactions. The first group includes predisposing factors, such as an individual tendency to insomnia. It includes biological and genetic factors, as well as gender, because, according to the author of this division - Spielman - women are more sensitive to sleeplessness. Additionally, older people are included, people with personality traits of excessive tidiness, scrupulousness and compulsion, as well as a positive family survey regarding insomnia [5-7]. The second group includes factors triggering insomnia. They include environmental and medical factors such as: stressors in both private and professional life, medical conditions, using psychoactive substances [4]. The last group include the so-called factors preserving insomnia that relate directly to the behaviors of people suffering from insomnia, such as: behavior leading to development of irregular hours of going to bed and getting up, concentrating their thoughts on the problem of a sleepless night, fear of another sleepless night, overdosing on sleeping pills and suffering from daytime sleepiness. This group of factors is very dangerous to people who suffers from insomnia, because they prevent proper functioning $[6,7]$.

There are various consequences of chronic untreated insomnia, and all of them have an impact on physical and mental health. Any sleep disorders increase the risk of developing a number of medical conditions that affect, among others, the musculoskeletal system, cardiovascular system, respiratory system and renal system [8]. Insomnia may cause accidents and other road incidences and have an impact on the number of accidents at work, e.g. among people operating heavy machinery or working at a high altitude. Factors influencing the work of drivers include their work time - the amount of time they spend driving their vehicle. Numerous factors may lead to a decrease in concentration in drivers; these include driving in heavy traffic, poor road visibility, having to divert focus to other additional tasks such as looking for a specific address in the case of ambulance drivers. Factors causing drivers to fall asleep behind the wheel are very often referred to as passive fatigue, and they include a monotonous drive or little traffic on the road [9, 10]. A significant threat to drivers caused by insomnia is loss of concentration, which may lead to an accident. Driver's fatigue is often compared to a state of alcohol intoxication, and studies show that a driver's ability to properly operate a vehicle after 17-19 hours of work decreases to a level similar to 0.5 blood alcohol level [11]. 
The most common causes of daytime sleepiness include chronic lack of sleep due to insomnia or an improper lifestyle, as well as not adhering to a proper sleep schedule [8]. The nature of a professional driver's work involves an irregular lifestyle, which makes it more difficult to follow a proper sleep pattern [10].

\section{Objectives}

The aim of the study was to estimate the frequency of occurrence of insomnia among professional drivers, taking into consideration daytime sleepiness, socio-demographic variables and hourly work organization. The authors seek the answer to the question: do problems with sleep among professional drivers lead to accidents and other road incidences?

\section{Material and methods}

In the course of the study, 150 questionnaires were distributed. The return rate was 94 questionnaires that were included in the study. Ultimately, the study was conducted on 94 professional drivers from the Zachodniopomorskie region: 24 (25.53\%) paramedics, 24 (25.53\%) police officers, 23 (24.47\%) fire fighter drivers and $23(24.47 \%)$ truck drivers. All respondents were male. They were $24-61$ years old (average age 35.35 \pm 8.19 ) (Table 1). A questionnaire was used with the following components: Athens Insomnia Scale (AIS), Epworth Sleepiness Scale (ESS) and an original questionnaire containing questions regarding socio-demographic data and health behaviors. The AIS scale consists of eight questions related to the occurrence of insomnia. Each question contains four answer variants that can score from 0 to 3 points. When answering the question, the respondent indicates a symptom which occurred at least three times a week in the last month. The AIS scale results are analyzed in the following manner: less than 5 points indicates lack of insomnia, from 6 to 10 - borderline norm, 10 points or more confirms insomnia. The Epworth Sleepiness Scale (ESS) allowed the authors to conduct a subjective evaluation of symptoms related to daytime sleepiness and consists of eight questions with answers scoring from 0 to 3 points. The respondents answer questions by indicating the probability of falling asleep in each of eight presented situations, where 0 means the respondent has never fallen asleep in a given situation, 1 - indicated a very low probability of falling asleep, 2 - often leads to falling asleep, and 3 - very high probability of falling asleep in a given situation. The ESS scale results are interpreted in the following way: 0-10 points - normal result, 11-14 points - mild sleepiness, 15-18 points - moderate daytime sleepiness, and results over 18 points indicate serious daytime sleepiness. The authors' own questionnaire contained questions about socio-demographic data, such as: age, height, weight and a question regarding the amount of coffee respondents drink during the day, monthly amount of work time and causing threat in traffic.

The study received the positive opinion of the Bioethical Commission (no. KB-0012/63/16).

\section{Statistical methods}

Statistical analysis was conducted with the use of descriptive statistics and statistical tests. Normal distribution was evaluated with the Shapiro-Wilk test. A Shapiro-Wilk test was performed to show that there was no normal distribution for the respondents' age in this study. Only the age of police officers had a normal distribution. Weight, height and BMI showed normal distribution. Statistical relationships and differences were analyzed with the following tests: ANOVA, Bartlet $\chi^{2}$, Pearson $\chi^{2}$ and Kruskal-Wallis $\mathrm{H}$-Test. The results were considered statistically significant if $p \leq 0.05$. Statistical analysis was conducted with Statistica 12 software.

\begin{tabular}{|c|c|c|c|c|}
\hline Variable & $\begin{array}{l}\text { Paramed- } \\
\text { ics }\end{array}$ & $\begin{array}{l}\text { Fire } \\
\text { fighters } \\
\text { drivers }\end{array}$ & $\begin{array}{l}\text { Truck } \\
\text { drivers }\end{array}$ & $\begin{array}{l}\text { Police } \\
\text { officers }\end{array}$ \\
\hline $\begin{array}{l}\text { Number of } \\
\text { respondents }\end{array}$ & $\begin{array}{l}24 \\
(25.53 \%)\end{array}$ & $\begin{array}{l}23 \\
(24.47 \%)\end{array}$ & $\begin{array}{l}23 \\
(24.47 \%)\end{array}$ & $\begin{array}{l}24 \\
(25.53 \%)\end{array}$ \\
\hline $\begin{array}{l}\text { Age [years] } \\
\text { mean } \\
\text { min-max }\end{array}$ & $\begin{array}{l}31 \\
24-56\end{array}$ & $\begin{array}{l}33 \\
27-51\end{array}$ & $\begin{array}{l}35 \\
24-61\end{array}$ & $\begin{array}{l}X \pm S D \\
35.25 \pm \\
5.31\end{array}$ \\
\hline $\begin{array}{l}\text { Weight [kg] } \\
X \pm S D\end{array}$ & $\begin{array}{l}87.33 \pm \\
11.39\end{array}$ & $\begin{array}{l}91.82 \pm \\
10.61\end{array}$ & $\begin{array}{l}90.55 \pm \\
12.11\end{array}$ & $\begin{array}{l}87.38 \pm \\
10.9\end{array}$ \\
\hline $\begin{array}{l}\text { Height }[\mathrm{cm}] \\
X \pm S D\end{array}$ & $\begin{array}{l}180.54 \pm \\
8.13\end{array}$ & $\begin{array}{l}182.57 \pm \\
5.91\end{array}$ & $\begin{array}{l}38.04 \pm \\
11.11\end{array}$ & $\begin{array}{l}182.17 \pm \\
7.13\end{array}$ \\
\hline $\begin{array}{l}B M I \\
X \pm S D\end{array}$ & $\begin{array}{l}26.86 \pm \\
3.78\end{array}$ & $\begin{array}{l}27.55 \pm \\
3.14\end{array}$ & $\begin{array}{l}28.69 \pm \\
3.54\end{array}$ & $\begin{array}{l}26.32 \pm \\
7.13\end{array}$ \\
\hline
\end{tabular}

Arithmetic mean \pm SD (minimum and maximum range).

\section{Results}

According to the AIS, insomnia was diagnosed in every seventh driver $(n=12 ; 12.8 \%)$, more frequently in truck drivers $(n=$ $4 ; 4.3 \%)$. Among the evaluated professional groups, truck drivers have the highest risk of occurrence of insomnia -10 respondents $(10.64 \%)$. In the group of evaluated paramedics, two respondents (2.13\%) were diagnosed with insomnia. The highest percentage of respondents falling into the normal range according to Athens Insomnia Scale was fire fighter drivers -15 respondents (15.96\%). Mild insomnia was found in 15 professional drivers (15.96\%), with the highest percentage in paramedics $(n=6 ; 6.38 \%)$. In the evaluated group, there were no respondents suffering from heavy daytime sleepiness (Figures 1 and 2).

A relationship between the age of respondents and occurrence of insomnia measured with the AIS was found. A statistically significant relationship was found regarding lack of insomnia and among respondents with borderline insomnia $(H=11.89 ; p=0.026)$. Borderline insomnia usually occurs among drivers older than 35 (Figure 3 ). The relationship between the age of respondents and daytime sleepiness was analyzed. People suffering from moderate daytime sleepiness are on average 35 years old. No statistically significant relationship between age and sleepiness was found $(H=1.91 ; p=0.38)$.

A statistically significant relationship between the weight of respondents and occurrence of insomnia was also not found $(H=3.93 ; p=0.14)$. Drivers with a median weight above $90 \mathrm{~kg}$ were more frequently on the borderline norm of insomnia than those with a weight below $90 \mathrm{~kg}$. After analysis, no relationship between the weight of drivers and daytime sleepiness was found $(H=0.44 ; p=0.80)$. Drivers weighing approximately $90 \mathrm{~kg}$ were in the group suffering from mild daytime sleepiness.

Statistical analysis was performed on the relationship between the occurrence of insomnia on the AIS and BMI. A more frequent occurrence of moderate insomnia was found among drivers with a BMI above 28 (Figure 4). Statistically significantly more often drivers with a BMI below 28 were within the norm (below 6 points) - they did not suffer from insomnia $(H=12.64$; $p=0.018$ ). Borderline statistical significance was found between the BMI of drivers and daytime sleepiness $(H=2.54 ; p=0.05)$. Drivers with BMI 27.5 did not experience sleepiness during the day, and the highest level of daytime sleepiness was experienced by drivers with a BMI above 29 .

The relationship between the monthly work hours and occurrence of insomnia was analyzed. Almost every third $(n=27$; 

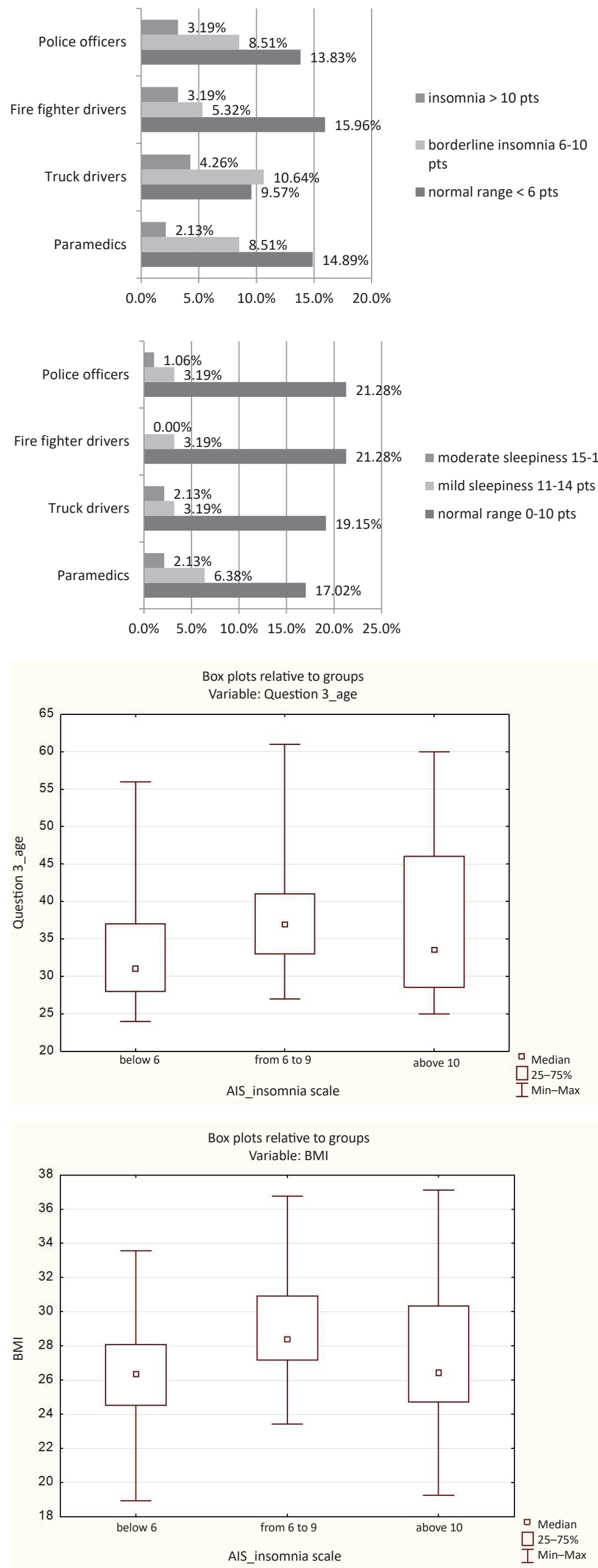

Figure 1. Evaluation of the occurrence of insomnia with the AIS

Figure 2. Evaluation of daytime sleepiness occurrence with the ESS

Figure 3. Relationship between insomnia and the age of respondents 
$28.72 \%)$ respondent had only one full-time job of 160 hours per month. In this group, there are 13 people (13.8\%) with sleeping disorders that borderline on insomnia and two people $(2.13 \%)$ with results indicating insomnia; no statistically significant relationship was found between the monthly work time of drivers and the occurrence of insomnia $\left(\chi^{2}=6.95 ; p=0.14\right)$ (Table 2). Analysis of the relationship between monthly work time and daytime sleepiness was also performed. Among all the respondents, 15 of them (15.96\%) suffered from mild daytime sleepiness. This group includes 6 drivers (6.38\%) who work over 200 hours in a month. The analysis did not show that the monthly work time of drivers has any statistically significant impact on the occurrence of daytime sleepiness on the ESS $\left(\chi^{2}=5.07 ; p=\right.$ 0.28) (Table 3).

The results of the conducted analysis indicate the existence of a strong relationship between insomnia and drivers posing a threat to road traffic $\left(\chi^{2}=19.95 ; p=0.005\right)$. In this group, 13 respondents (13.83\%) had borderline insomnia, and regular insomnia was diagnosed in 10 people (10.64\%) who admitted to causing a real threat to road traffic due to lack of sleep (Table 4). Respondents were asked to indicate whether they had ever posed a real threat to road traffic during their professional ca- reer. 32 people $(34.04 \%)$ admitted to posing a threat to road traffic. The relationship between daytime sleepiness and posing a threat to road traffic was also analyzed. No statistically significant relationships were found $\left(\chi^{2}=3.18 ; p=0.20\right.$ ) (Table 4).

Coffee is considered an energizing drink, and drivers were asked how many cups of coffee they drink during the day. Among all the respondents, 83 of them drink coffee $(86.17 \%)$, and 11 respondents $(11.70 \%)$ do not drink coffee at all. In the group of coffee drinkers, 23 people $(24.47 \%)$ drink one cup of coffee a day, while the majority drink 1,2 and 3 cups of coffee a day. Among 12 people with insomnia (12.8\%), all of them drink from 1 to 3 cups of coffee a day. Half of them ( $n=6 ; 6.4 \%)$ drink 3 and more cups of coffee a day (Table 5). No statistically significant relationship between age and sleepiness was found $(H=15.31 ; p=0.05)$. Statistical analysis was conducted on the influence of drinking coffee on experiencing daytime sleepiness - no statistically significant relationships were found $\left(\chi^{2}=8.35\right.$; $p=0.40$ ) (Table 5).

Analysis of the influence of insomnia on the occurrence of daytime sleepiness did not show any statistically significant relationships in the studied group of professional drivers $\left(\chi^{2}=7.65\right.$; $p=0.10$ ) (Table 6).

\begin{tabular}{|c|c|c|c|c|c|c|}
\hline \multirow{2}{*}{$\begin{array}{l}\text { Work hours in } \\
\text { a month }\end{array}$} & \multicolumn{4}{|c|}{ Insomnia on the AIS } & \multirow[t]{2}{*}{$x^{2}$} & \multirow[t]{2}{*}{$\boldsymbol{p}$} \\
\hline & $\begin{array}{l}\text { Norm } \\
n(\%)\end{array}$ & $\begin{array}{l}\text { Norm verge } \\
n(\%)\end{array}$ & $\begin{array}{l}\text { Insomnia } \\
n(\%)\end{array}$ & $\begin{array}{l}\text { Total } \\
n(\%)\end{array}$ & & \\
\hline 160 & \begin{tabular}{|l}
12 \\
$(12.77 \%)$
\end{tabular} & \begin{tabular}{|l}
13 \\
$(13.83 \%)$
\end{tabular} & $\begin{array}{l}2 \\
(2.13 \%)\end{array}$ & \begin{tabular}{|l|}
27 \\
(28.72\%)
\end{tabular} & \multirow[t]{3}{*}{6.95} & \multirow[t]{3}{*}{0.14} \\
\hline $161-200$ & \begin{tabular}{|l}
29 \\
$(30.85 \%)$
\end{tabular} & $\begin{array}{l}11 \\
(11.70 \%)\end{array}$ & \begin{tabular}{|l}
5 \\
$(5.32 \%)$ \\
\end{tabular} & \begin{tabular}{|l}
45 \\
$(47.87 \%)$
\end{tabular} & & \\
\hline$>200$ & \begin{tabular}{|l}
10 \\
$(10.64 \%)$
\end{tabular} & \begin{tabular}{|l}
7 \\
(7.45\%)
\end{tabular} & \begin{tabular}{|l|}
5 \\
(5.32\%)
\end{tabular} & \begin{tabular}{|l|}
22 \\
(23.40\%)
\end{tabular} & & \\
\hline Total & $\begin{array}{l}51 \\
(54.26 \%)\end{array}$ & $\begin{array}{l}31 \\
(32.98 \%)\end{array}$ & $\begin{array}{l}12 \\
(12.77 \%)\end{array}$ & $\begin{array}{l}94 \\
(100.00 \%)\end{array}$ & & \\
\hline
\end{tabular}

\begin{tabular}{|c|c|c|c|c|c|c|}
\hline \multirow{2}{*}{$\begin{array}{l}\text { Work hours in } \\
\text { a month }\end{array}$} & \multicolumn{4}{|c|}{ Daytime sleepiness on the ESS } & \multirow[t]{2}{*}{$x^{2}$} & \multirow[t]{2}{*}{$p$} \\
\hline & $\begin{array}{l}\text { Norm } \\
n(\%)\end{array}$ & $\begin{array}{l}\text { Mild sleepiness } \\
n(\%)\end{array}$ & $\begin{array}{l}\text { Moderate sleepiness } \\
n(\%)\end{array}$ & $\begin{array}{l}\text { Total } \\
n(\%)\end{array}$ & & \\
\hline 160 & $\begin{array}{l}21 \\
(22.34 \%) \\
\end{array}$ & \begin{tabular}{|l}
5 \\
$(5.32 \%)$ \\
\end{tabular} & \begin{tabular}{|l}
1 \\
$(1.06 \%)$ \\
\end{tabular} & \begin{tabular}{|l}
27 \\
$(28.72 \%)$ \\
\end{tabular} & \multirow[t]{3}{*}{5.07} & \multirow[t]{3}{*}{0.28} \\
\hline $161-200$ & $\begin{array}{l}39 \\
(41.49 \%)\end{array}$ & \begin{tabular}{|l}
4 \\
$(4.26 \%)$ \\
\end{tabular} & \begin{tabular}{|l}
2 \\
$(2.13 \%)$ \\
\end{tabular} & \begin{tabular}{|l}
45 \\
$(47.87 \%)$ \\
\end{tabular} & & \\
\hline$>200$ & $\begin{array}{l}14 \\
(14.89 \%) \\
\end{array}$ & \begin{tabular}{|l|}
6 \\
$(6.38 \%)$ \\
\end{tabular} & $\begin{array}{l}2 \\
(2.13 \%) \\
\end{array}$ & \begin{tabular}{|l}
22 \\
$(23.40 \%)$ \\
\end{tabular} & & \\
\hline Total & $\begin{array}{l}74 \\
(78.72 \%)\end{array}$ & $\begin{array}{l}15 \\
(15.96 \%)\end{array}$ & \begin{tabular}{|l}
5 \\
$(5.31 \%)$
\end{tabular} & $\begin{array}{l}94 \\
(100.00 \%)\end{array}$ & & \\
\hline
\end{tabular}

\begin{tabular}{|c|c|c|c|c|c|}
\hline \multicolumn{3}{|c|}{$\begin{array}{l}\text { Athens Insomnia Scale } \\
\chi^{2}=19.95 ; p=0.005\end{array}$} & \multicolumn{3}{|c|}{$\begin{array}{l}\text { Epworth Sleepiness Scale } \\
\chi^{2}=3.18 ; p=0.20\end{array}$} \\
\hline $\begin{array}{l}\text { Norm } \\
n(\%)\end{array}$ & $\begin{array}{l}\text { Norm verge } \\
n(\%)\end{array}$ & $\begin{array}{l}\text { Insomnia } \\
n(\%)\end{array}$ & $\begin{array}{l}\text { Norm } \\
n(\%)\end{array}$ & $\begin{array}{l}\text { Mild sleepiness } \\
n(\%)\end{array}$ & $\begin{array}{l}\text { Moderate sleepiness } \\
n(\%)\end{array}$ \\
\hline $\begin{array}{l}9 \\
(9.57 \%)\end{array}$ & \begin{tabular}{|l|}
13 \\
$(13.83 \%)$
\end{tabular} & $\begin{array}{l}10 \\
(10.64 \%)\end{array}$ & \begin{tabular}{|l|}
22 \\
$(23.40 \%)$
\end{tabular} & \begin{tabular}{|l}
8 \\
$(8.51 \%)$
\end{tabular} & \begin{tabular}{|l|}
2 \\
$(2.13 \%)$
\end{tabular} \\
\hline
\end{tabular}




\begin{tabular}{|c|c|c|c|c|c|c|c|}
\hline \multirow{2}{*}{$\begin{array}{l}\text { Number of cups of coffee } \\
\text { drank during the day }\end{array}$} & \multicolumn{3}{|c|}{ Athens Insomnia Scale (AIS) } & \multicolumn{3}{|c|}{ Epworth Sleepiness Scale (ESS) } & \multirow[b]{2}{*}{$\begin{array}{l}\text { Total } \\
n(\%)\end{array}$} \\
\hline & $\begin{array}{l}\text { Norm } \\
n(\%)\end{array}$ & $\begin{array}{l}\text { Norm verge } \\
n(\%)\end{array}$ & $\begin{array}{l}\text { Insomnia } \\
n(\%)\end{array}$ & $\begin{array}{l}\text { Norm } \\
n(\%)\end{array}$ & $\begin{array}{l}\text { Mild sleepiness } \\
n(\%)\end{array}$ & \begin{tabular}{|l} 
Moderate \\
sleepiness \\
$n(\%)$ \\
\end{tabular} & \\
\hline 0 & $\begin{array}{l}8 \\
(8.51 \%)\end{array}$ & $\begin{array}{l}3 \\
(3.19 \%)\end{array}$ & $\begin{array}{l}0 \\
(0.00 \%)\end{array}$ & $\begin{array}{l}9 \\
(9.57 \%)\end{array}$ & $\begin{array}{l}1 \\
(1.06 \%)\end{array}$ & $\begin{array}{l}1 \\
(1.06 \%)\end{array}$ & $\begin{array}{l}11 \\
(11.7 \%)\end{array}$ \\
\hline 1 & $\begin{array}{l}12 \\
(12.77 \%)\end{array}$ & $\begin{array}{l}7 \\
(7.45 \%)\end{array}$ & $\begin{array}{l}4 \\
(4.26 \%)\end{array}$ & $\begin{array}{l}19 \\
(20.21 \%)\end{array}$ & $\begin{array}{l}4 \\
(4.26 \%)\end{array}$ & $\begin{array}{l}0 \\
(0.00 \%)\end{array}$ & $\begin{array}{l}23 \\
(24.5 \%)\end{array}$ \\
\hline 2 & $\begin{array}{l}17 \\
(18.09 \%)\end{array}$ & $\begin{array}{l}9 \\
(9.57 \%)\end{array}$ & $\begin{array}{l}2 \\
(2.13 \%)\end{array}$ & $\begin{array}{l}22 \\
(23.40 \%)\end{array}$ & $\begin{array}{l}3 \\
(3.19 \%)\end{array}$ & $\begin{array}{l}3 \\
(3.19 \%)\end{array}$ & $\begin{array}{l}28 \\
(29.8 \%)\end{array}$ \\
\hline 3 & $\begin{array}{l}14 \\
(14.89 \%)\end{array}$ & $\begin{array}{l}10 \\
(10.64 \%)\end{array}$ & $\begin{array}{l}3 \\
(3.19 \%)\end{array}$ & $\begin{array}{l}21 \\
(22.34 \%)\end{array}$ & $\begin{array}{l}6 \\
(6.38 \%)\end{array}$ & $\begin{array}{l}0 \\
(0.00 \%)\end{array}$ & $\begin{array}{l}27 \\
(28.7 \%)\end{array}$ \\
\hline Above 3 & $\begin{array}{l}0 \\
(0.00 \%)\end{array}$ & $\begin{array}{l}2 \\
(2.13 \%)\end{array}$ & $\begin{array}{l}3 \\
(3.19 \%)\end{array}$ & $\begin{array}{l}3 \\
(3.19 \%)\end{array}$ & $\begin{array}{l}1 \\
(1.06 \%)\end{array}$ & $\begin{array}{l}1 \\
(1.06 \%)\end{array}$ & $\begin{array}{l}5 \\
(5.31 \%)\end{array}$ \\
\hline Total & $\begin{array}{l}51 \\
(54.26 \%)\end{array}$ & $\begin{array}{l}31 \\
(32.98 \%)\end{array}$ & \begin{tabular}{|l}
12 \\
$(12.77 \%)$
\end{tabular} & $\begin{array}{l}74 \\
(78.72 \%)\end{array}$ & $\begin{array}{l}15 \\
(15.96 \%)\end{array}$ & \begin{tabular}{|l}
5 \\
$(5.32 \%)$
\end{tabular} & $\begin{array}{l}94 \\
(100 \%)\end{array}$ \\
\hline$\chi^{2} ; p$ & \multicolumn{3}{|c|}{$\chi^{2}=15.31 ; p=0.05$} & \multicolumn{3}{|c|}{$\chi^{2}=8.35 ; p=0.40$} & \\
\hline
\end{tabular}

\begin{tabular}{|c|c|c|c|c|c|c|}
\hline \multirow{2}{*}{$\begin{array}{l}\text { Scale } \\
\text { Athens Insomnia Scale }\end{array}$} & \multicolumn{4}{|c|}{ Epworth Sleepiness Scale } & \multirow[t]{2}{*}{$x^{2}$} & \multirow[t]{2}{*}{$p$} \\
\hline & Norm & Mild sleepiness & $\begin{array}{l}\text { Moderate sleepi- } \\
\text { ness }\end{array}$ & Total & & \\
\hline Norm & $\begin{array}{l}43 \\
(45.74 \%) \\
\end{array}$ & $\begin{array}{l}6 \\
(6.38 \%) \\
\end{array}$ & $\begin{array}{l}2 \\
(2.13 \%) \\
\end{array}$ & $\begin{array}{l}51 \\
(54.26 \%) \\
\end{array}$ & \multirow[t]{4}{*}{7.655} & \multirow[t]{4}{*}{0.10} \\
\hline Norm verge & $\begin{array}{l}25 \\
(26.60 \%)\end{array}$ & $\begin{array}{l}4 \\
(4.26 \%)\end{array}$ & $\begin{array}{l}2 \\
(2.13 \%)\end{array}$ & $\begin{array}{l}31 \\
(32.98 \%)\end{array}$ & & \\
\hline Insomnia & $\begin{array}{l}6 \\
(6.38 \%) \\
\end{array}$ & $\begin{array}{l}5 \\
(5.32 \%) \\
\end{array}$ & $\begin{array}{l}1 \\
(1.06 \%)\end{array}$ & $\begin{array}{l}12 \\
(12.77 \%)\end{array}$ & & \\
\hline Total & $\begin{array}{l}74 \\
(78.72 \%)\end{array}$ & $\begin{array}{l}15 \\
(15.96 \%)\end{array}$ & $\begin{array}{l}5 \\
(5.32 \%)\end{array}$ & $\begin{array}{l}94 \\
(100.00 \%)\end{array}$ & & \\
\hline
\end{tabular}

\section{Discussion}

Between 2007 and 2014 in Poland, studies were conducted regarding accidents caused by driver fatigue or falling asleep at the wheel. In 7 years, there were 377 accidents caused by driver fatigue. As a result of these incidents, 572 people were injured, and there were 58 fatalities [12]. As early as 1995, the US Department of Transportation had declared that vehicles operated by drivers suffering from fatigue is one of the major problems of professional transportation, and the drivers themselves pose a significant threat to public safety [10]. In studies conducted by Philip et al., almost $17 \%$ of professional drivers complained about having sleeping disorders, and more than $30 \%$ of the respondents had participated in a road accident, where half of these incidents were caused by major sleepiness. In the study, the authors have not proven that variables such as age, gender or marital status had a statistically significant influence on the occurrence of insomnia among drivers [13]. The authors' own research pointed to similar indications that not all analyzed socio-demographic factors had an influence on the occurrence of insomnia in the studied group of drivers. They also indicated a relationship between insomnia and the age of the drivers - respondents in the group of those not suffering from insomnia were younger than those at risk of the occurrence of insomnia. Own studies indicate that the more cups of coffee drunk by respondents, the more often they are prone to the occurrence of insomnia. No relationship was found between the number of cups of coffee drunk during the day and daytime sleepiness. Studies conducted by Zużewicz and Konarska have shown that drivers use various methods to prevent daytime sleepiness. The easiest and most often used remedy for sleepiness is caffeine, which is an ingredient in many food and drink products [14]. Minarowski et al. conducted studies on a group of 103 professional drivers aged 24 to 62 . The average BMI value was 28 . It was found that drivers with a high risk of sleep apnea had higher BMI values [15]. Moreover, 23 drivers (22\%) admitted to having to stop their vehicle during work due to increased sleepiness [15]. In the authors' own research, higher BMI values in drivers indicated a higher risk of insomnia. In studies conducted by Ozoh et al. on a group of 500 professional drivers aged 20 to 73 with an average BMI value of 26 , heavy daytime sleepiness was found in 72 drivers (14.4\%) [16]. Moreover, 61 interviewed drivers $(12.2 \%)$ had a car accident in the past, but there was no statistically significant relationship found between daytime sleepiness and the risk of causing a road accident $(p=0.1)$ [16]. The occurrence of insomnia in the population, troubles with falling asleep and frequent waking up during the night is estimated at 6-15\% [17]. Sleep disorders are statistically more often found in people working in shifts, particularly at night [18]. In studies conducted by Smolensky et al., it was found that among drivers experiencing daytime sleepiness, the risk of posing a threat to road traffic was more than twice as high as in drivers without sleeping disorders [19]. The authors' own research did not show a statistically significant relationship between daytime sleepiness and posing a threat to road traffic. 


\section{Conclusions}

1. Insomnia most often occurs in truck drivers. Drivers older than 35 and those with a BMI above 28 are in groups with the highest risk of suffering from insomnia.

2. Only every third driver had one full-time job, but the amount of work hours of drivers has no influence on in- somnia and daytime sleepiness.

3. Drivers with insomnia more frequently pose a threat to road traffic, whereas daytime sleepiness does not result in respondents posing a threat to road traffic.

4. Drinking coffee has no impact on insomnia and daytime sleepiness, but this may be the result of the number of cups respondents drink during the day.

Source of funding: This work was funded by the authors' resources. Conflict of interest: The authors declare no conflict of interests.

\section{References}

1. Wojtas A, Ciszewski S. Epidemiologia bezsenności. Psychiatria 2011; 8(3): 79-83 (in Polish).

2. Mroczek B, Mazurek D, Rotter I, et al. Ocena występowania bezsenności wśród ludzi w wieku produkcyjnym. Fam Med Prim Care Rev 2009; 11(3): 428-429 (in Polish).

3. Wolińska W, Pawlak IE, Mroczek B. Analysis of insomnia in those over 60 year of age. Fam Med Primary Care Rev 2016; 18(4): $482-485$.

4. Spielman AJ, Caruso LS, Glovinsky PB. A behavioral perspective on insomnia treatment. Psychiatr Clin North Am 1987; 10(4): 397-403.

5. Fernandez-Mendoza J, Vela-Bueno A, Vgontzas AN, et al. Cognitive-emotional hyperarousal as a premorbit characteristic of individuals vulnerable to insomnia. Psychosom Med 2010; 72(4): 397-403.

6. Schmidt RE, Gay P, Ghisletta P, et al. Linking impulsivity to dysfunctional thought control and insomnia: a structural equation model. J Sleep Res 2010; 19(1 Pt 1): 3-11.

7. Skalski M, Fornal M, Szelenberger W. Rodzinne występowanie bezsenności nieorganicznej. Sen 2006; 6(1): 1-7 (in Polish).

8. Prusiński A. Bezsenność i inne zaburzenia snu. $2^{\text {nd }}$ ed. Warszawa: Wydawnictwo Lekarskie PZWL; 2007: 12-43 (in Polish).

9. Gimeno PT, Cerezuela GP, Montanes MC. On the concept and measurement of driver drowsiness, fatique and inattention: Implications for countermeasures. Int J Vehicle Design 2006; 42(1/2): 67-86.

10. Makowiec-Dąbrowska T, Bortkiewicz A, Siedlecka J, et al. Wpływ zmęczenia na zdolność prowadzenia pojazdów. Med Pr 2011; 62(3): 281-290 (in Polish).

11. Williamson AM, Feyer AM. Moderate sleep deprivation products impairments in cognitive and motor performance equivalent to legally prescribed levels of alcohol intoxication. Occup Environ Med 2000; 57(10): 649-655.

12. Road events database [cited 03.05.17]. Available from URL: http://www.baza.fril.org.pl/index.php?go=index.

13. Philip P, Sagaspe $\mathrm{P}$, Lagarde $\mathrm{E}$, et al. Sleep disorders and accidental risk in a large group of regular registered highway drivers. Sleep Med Rev 2010; 11(10): 973-979.

14. Zużewicz K, Konarska M. Kofeina - sposób na poprawę sprawności działania i zapobieganie senności. Bezp Pr Nauk Prakt 2008; 5(440): 10-14 (in Polish).

15. Minarowski Ł, Chwieśko-Minarowska S, Czaban M, et al. Ocena występowania wzmożonej senności w ciągu dnia oraz ryzyka obturacyjnego bezdechu podczas snu u kierowców zawodowych komunikacji miejskiej. Med Pr 2015; 66(5): 679-685 (in Polish).

16. Ozoh OB, Okubadejo NU, Akanbi MO, et al. High-risk of obstructive sleep apnea and excessive daytime sleepiness among commercial intra-city drivers in Lagos metropolis. Niger Med J 2013; 54(4): 224-229.

17. Ohayon MM, Smirne S. Prevalence and consequence of insomnia disorder in the general population in Italy. Sleep Med 2002; 3(2): $115-120$.

18. Ohyaon MM, Roth T. What are the contributing factors for insomnia in the general population? J Psychosom Res 2001; 51: 745-755.

19. Smolensky MH, Di Milia L, Ohayon MM, et al. Sleep disorders, medical conditions, and road accident risk. Accid Anal Prev 2011; 43(2): 533-548.

Tables: 6

Figures: 4

References: 19

Received: 30.04 .2017

Revised: 27.06.2017

Accepted: 30.06 .2017

Address for correspondence:

Weronika Wolińska, MA

Zakład Nauk Humanistycznych w Medycynie PUM

ul. Chłapowskiego 11

70-103 Szczecin

Polska

Tel.: +48 508 301-892

E-mail: weronika.wolinska@pum.edu.pl,weronikawolinska@poczta.fm 